Report on the Crocodile River Iron Deposits. By P. A. WAGNER. Geological Survey of the Union of South Africa, Memoir No. 17. pp. 65, with 12 plates and 5 figures. 1921. THESE deposits of banded hæmatite ore are situated in the 1 northern part of the Rustenburg district of the Transvaal, in a rather inaccessible district, 68 miles from the nearest railway. They lie immediately above the dolomite of the Transvaal System, and belong to the usual type of banded ironstone that is so common in many localities. They include red and black, black and grey, and dull-brown varieties, as well as calico-rock, and may be described as essentially banded ferruginous cherts with a varying proportion of iron oxide; the iron-content ranges from 16 to 44 per cent, but the silica is usually very high. It seems highly probable that when a railway is constructed these deposits will become of economic importance.

\title{
CORRESPONDENCE.
}

\section{PALAONTOLOGICAL ABSTRACTS.}

Sir,- - You allowed me in April, 1920, to draw attention to the alliance of the Revue Critique de Paléozoologie with the Review of Geology. May I remind your readers that the work of preparing or editing abstracts of all papers on fossil animals and plants is still carried on by M. Cossmann, and that he is particularly anxious to receive either author's abstracts or separate copies of all papers by British palæontologists.

Will those who respond to his request kindly note the new address : from November to May, 21 Rue Montpensier, Pau (B.-P.), France; from June to October, 2 Boulevard Sadi-Carnot, Enghien. (S. \& 0.), France.

\section{F. A. Bather.}

\section{THE RAISED BEACH AT EASINGTON.}

SIR,--Having had the privilege of examining the Durham coastsections last summer under the guidance of Dr. Trechmann and Dr. Woolacott, I can thoroughly appreciate the importance of their discoveries among the Pleistocene deposits, which have introduced new factors into the complicated problems of the East British drifts.

On seeing the Raised Beach at Easington, discovered by Dr. Woolacott and discussed by him in your current (February) issue, I was immediately satisfied that it was an actual marine shoredeposit resting upon its original rock-shelf, and a later visit confirmed me in this opinion. But $I$ saw in the same neighbourhood, and elsewhere in the county, other sandy and gravelly deposits, to which a marine origin has been assigned, that appeared to me to be all of the usual fluvio-glacial type, carrying no positive evidence of marine conditions and differing essentially from the Easington Beach. 